\title{
STUDIE
}

\section{LAMENTATIO NIGROPONTIS: AN UNKNOWN PRINT OF SIXTUS RIESSINGER, A PROTOTYPOGRAPHER OF NAPLES*}

\author{
Kamil Boldan (Prague)
}

\begin{abstract}
The collection of incunabula in the National Library of the Czech Republic contains a previously unknown print published by the Naples printer Sixtus Riessinger at the end of 1470 or, more likely, in 1471. The four-folio Lamentatio Nigropontis complements the collection of 16 hitherto known prints that directly responded to the conquest of the island of Negroponte (Euboea), a colony of the Republic of Venice, by the Ottoman army of Sultan Mehmed II in 1470. The article contextualises the circumstances of the publication of one of the first prints of Naples.
\end{abstract}

Keywords: incunabula - printed Turcica - printing in Naples - Ottoman threat - siege of Negroponte

Before looking at the print published by the Naples prototypographer Sixtus Riessinger, it is necessary to draw attention to the historical event that preceded it. After the conquest of Constantinople in 1453, the Ottoman Empire subjugated other territories in the Balkans to reinforce its position there. The Ottoman expansion jeopardised the business interests of the Republic of Venice in the eastern Mediterranean. During the Ottoman-Venetian naval war (1463-1479), La Serenissima was soon defeated and its overseas possessions (Stato di Mar) that were its mainstays of international trade were significantly reduced. The Ottoman sultan Mehmed II (known as Mehmed the Conqueror), who already controlled continental Greece and the Peloponnese, achieved another success 17 years after the downfall of the rest of the Byzantine Empire. After Crete, the island of Euboea was the second largest Venetian colony in the Aegean Sea. The Venetians called its capital Chalcis and the island Negroponte. They were well aware that Negroponte could be the next target as its port was the base for operations of their military galleys. Therefore, they intensified the fortification of the city, supplied the arsenal, and prepared for a long siege. ${ }^{1}$

In mid-June 1470, an Ottoman fleet commanded by Grand Vizier Mahmud Pasha and comprising 400 vessels of various types according to some reports disembarked near the island.
At the same time, a Turkish army led by Mehmed II approached from the mainland and traversed the strait that separated the island on a pontoon bridge. Historical sources record the certainly exaggerated number of 200 thousand Turkish soldiers who besieged the city. ${ }^{2}$ The Turkish fleet outnumbered the Venetians several times. The Venetian fleet did get close, but without daring to counterattack and help the defenders. It took five attacks before the Turks penetrated the fortification on 12 July, broke into the city, and began to kill all the men. Soon, they occupied the entire island. The loss of Negroponte weakened the Republic of Venice as a maritime power. The event was a clear manifestation of the increasing naval strength of the Ottoman Empire, which could now directly attack Italy. ${ }^{3}$

The reports on the massacre first reached Italy at the beginning of August and aroused horror in Venice and elsewhere. Pope Paul II made an effort to calm the disputes between the Italian states and to form a union to defend Italy. The renewal of the Italian League, originally concluded in $1454 / 1455$, was also supported by Venetian diplomacy. For a while, the contentions between Ferdinand I (Ferrante), King of Naples (1458-1494), and the pope subsided as well. In December 1470, the league was restored, but it did not last long in the unstable political situation of Italy, nor did it lead to any joint military body against the Ottoman Empire. ${ }^{4}$

\footnotetext{
* The article was written with the institutional support of the long-term conceptual development of the National Library of the Czech Republic as a research organisation provided by the Ministry of Culture of the Czech Republic.

KODER 1973, pp. 56-60, 65-66.

2 KODER 1973, p. 60.

3 KODER 1973, pp. 60-62; SETTON 1978, esp. pp. 298-305; BABINGER 1978, pp. 279-284; HOUSLEY 1992, pp. 23, 110-111; MESERVE 2006, pp. 440-442; SCHMITT 2007, p. 572.

${ }^{4}$ PASTOR 1904, pp. 431-439; PONTIERI 1969, pp. 248-253; MERTENS 1991, pp. 75-77; SCHMITT 2007, pp. 578-580; MESERVE 2006, pp. 447-454.
} 
During his pontificate (1464-1471), Pope Paul II prioritised the fight against the Bohemian heresy and King George of Poděbrady instead of dealing with the anti-Ottoman crusade. In order to halt the advancement of the Ottoman Turks into the Balkans, he financially supported the Albanian commander Skanderbeg and the Hungarian King Matthias Corvinus, the latter of whom led the campaign against George of Poděbrady in 1468. The Bohemian war thus blocked the Central European military forces that could have been used against the Turks. Paul's successor Sixtus IV (1471-1482) prepared the anti-Turkish crusade more vigorously. ${ }^{5}$

The Siege of Negroponte took place during the time of the rapid spread of book printing in Italy. It was the first foreign country where the knowledge of the new, Germaninvented letterpress technique had been brought by German printers. The first printing shop in Italy was established by the clergymen Conrad Sweynheym and Arnold Pannartz at the Benedictine Abbey of Subiaco in 1465. At the very beginning of the 1470 s, the first printing shops emerged in several prominent Italian cities. As early as 1472, they surpassed German printing shops in the number of the prints offered. ${ }^{6}$ Moreover, the Roman type provided Italian prints with a more up-to-date layout compared to those to the north of the Alps, in which Gothic script long prevailed. Especially northern Italy, the largest paper producer in Europe, had a much denser network of printing shops.

After the fall of Constantinople, the Gutenberg workshop in Mainz became involved in the anti-Turkish campaign, ${ }^{7}$ at first printing only a limited number of anti-Turkish prints. Their amount first increased in 1470-1472 and then in 14801482. The fall of Negroponte was one of the first contemporary events to arouse a great response in the new media. Book printing made the distant event more urgent and helped to advance the Turkish danger for a broader public debate. ${ }^{8}$

The American historian Margaret Meserve has researched a collection of the anti-Turkish prints that at least partially dealt with the fall of Negroponte. She has demonstrated that they combined features of Italian Humanism, politics and propaganda with communication and information technologies. Nevertheless, rather than with the 'news', they provided already informed readers with analyses and literary reflections; according to Meserve, they represent 'the first glimmers of a European news industry'. ${ }^{9}$ She studied sixteen bibliographic items from 1470-1472, fourteen of which were published in Italy, one in Paris in the first French printing shop, and one in Cologne. ${ }^{10}$ In terms of genre, they are compositions of poetry, consolation notes, and orations. They were aimed at supporting the idea of a new
anti-Turkish crusade and appealed to Italian rulers and other European monarchs. Two of the texts were dedicated to the influential Cardinal Bessarion (c. 1403-1472), a Humanist scholar, a leader of the Greek exiles, and the most vigorous promoter of the crusade. In his Epistolae et orationes contra Turcos, written after the fall of Negroponte, he criticises the previous indifference of Italian rulers and appeals to them for unity and joint defence in time of danger. One of the texts is addressed to Bessarion's namesake, the abbot of the Benedictine Monastery in Naples. The cardinal expressed his pleasure in learning that King Ferrante of Naples had decided to join in the anti-Turkish war. ${ }^{11}$ This crucial political treatise was published in Paris in 1471, and its Italian translation was issued in Venice in the same year. ${ }^{12}$

The mostly thin ephemera have survived very rarely. The collections of the National Library of the Czech Republic include a unique print that has thus far been passed unnoticed by incunabulists, and even Meserve was not familiar with it. This singular copy is part of a Sammelband comprising eleven quarto-format incunabula printed over a relatively long time, from about 1470 to 1497 . It was assembled by an unknown owner, who commissioned a half-leather binding. The terminus ante quem is the year 1506, written additionally on the front flyleaf. Fol. A1r, containing the title of the first print, includes a later ownership inscription, 'Ex libris Johannis Hagelii [de Raversperg]', from the turn of the 17th century. The same place shows the note 'Collegii Soc. Jesu Commotovii ex pio legato domini infra scripti [anno 1634] '. ${ }^{13}$ The book was deposited in the Chomutov library along with numerous prints that the little known Johannes Hagelius bequeathed to the Jesuit College in Chomutov, North Bohemia, in 1634. When the Society of Jesus was dissolved in 1773, the book was transferred to the former Public and University Library, a precursor of the present-day National Library. It comprises several thin anti-Turkish prints:

Hilduinus: Vita Sancti Dionysii (ed. Nicolaus Bernauer) Nuremberg, Caspar Hochfeder, [about 1497]

GW 12475. ISTC ih00272000

Bound with:

1

Pius II, Pont. Max.: Epistola ad Mahumetem

[Chelmno?, Printer of Leo Papa, not after 1476]

GW M33644. ISTC ip00700200

2

Hieronymus: Aureola ex floribus s. Hieronymi contexta

[Rome, Adam Rot, about 1474]

GW M07945. ISTC ih00156000

\footnotetext{
${ }^{5}$ PAULUS 1923, pp. 202-204; BAK 2004, pp. 124-126; HOUSLEY 2012, p. 12; KALOUS 2017, pp. 71, 155-157, 161-162.

${ }^{6}$ See the ISTC database.

${ }^{7}$ For example SCHNEIDER 2000, pp. 194-196, 208; EISERMANN 2011, pp. 124-126; DÖRING 2013 , pp. 39-66.

${ }^{8}$ DÖRING 2013, pp. 29-30, 75, a list of anti-Turkish prints from 1470-1472 on pp. 221-230; PETTEGREE 2014, pp. 59, 67, 140.

${ }^{9}$ MESERVE 2006, p. 473.

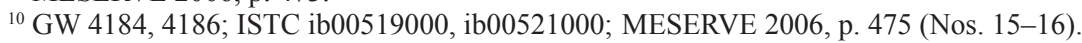

${ }^{11}$ PG, Vol. 161, cols. 647-648.

${ }^{12}$ MOHLER 1923-1942, Bd. 1, pp. 416-417; MESERVE 2006, p. 475; PAPPAS 2014; MUREŞAN 2017.

${ }^{13}$ Prague, National Library of the Czech Republic, shelf mark 44.G.75. The year was added based on a detailed note in the volume 40.E.6, the name after the more complete form in the volume 43.G.20.
} 
Suetonius Tranquillus, Gaius: De grammaticis et rhetoribus Florence, Apud Sanctum Jacobum de Ripoli, 1478

GW M44184. ISTC is00814

4

Thegliatius, Stephanus: Sermo contra Turcorum persecutionem

[Rome, Eucharius Silber, after 27 Dec 1480]

GW M45748. ISTC it00126000

5

Barbarus, Hermolaus: Oratio ad Fridericum III. Imperatorem et Maximilianum I. Regem Romanorum

[Rome, Stephan Plannck, after 13 Aug 1486]

GW 3345. ISTC ib00105000

6

Lamentatio Nigropontis ('Non equo animo')

Naples, [Sixtus Riessinger, after 13 Nov] 1470 [rather 1471]

GW M2711250. ISTC i100029039 (short-title records based on the author's report)

4to. Collation: $\left[\mathrm{a}^{4}\right]$. [4] leaves. 27 lines. Types: 2:97R; 3:180G (only on [a1r], line 1). Initial space.

Leaf [a1r]: [ $\left.{ }^{1}\right]$ On equo animo: "nec tranquilla mente: nec [iccis oculis \| tuas legi et iterum atq[ue] iterum relegi lillteras pater reuerendi / fime ... Leaf [a4v], line 18: ... Iter[um] uale et $p$ [ro] fillde ora: ut uales exclama: et corda filldeliu[m] [con]tra magumettum confirma: $\| N E A P O L I$ ANNO.M.\|CCCC.LXX.\|

\section{7}

Chieregatus, Leonellus: Epistola ad Georgium praepositum Basiliensem data

[Rome], Bartholomaeus Guldinbeck, [after 18 Oct 1482]

GW 6616. ISTC ic00451000

8

Lollius, Antonius: Oratio Circumcisionis dominicae coram Innocentio VIII. pontifice maximo habita

[Rome, Stephan Plannck, after 1 Jan 1485]

GW M18703. ISTC i100273000

9

Politianus, Angelus: Pactianae coniurationis commentarium [Rome, Johannes Bulle, after 26 Apr 1478]

GW M34740. ISTC ip00892000

10

Aurelius Victor, Sextus: De viris illustribus

Florence, Apud Sanctum Jacobum de Ripoli, 1478

GW M50381. ISTC ia01387000
A more detailed analysis of the Naples incunabulum will be preceded by a brief outline of the professional career of its printer. Sixtus Riessinger (c. 1440/1445 - not before 1506) was one of the first typographers in Italy. He most likely came from Sulz am Neckar, although he stated Strasbourg as the place of his birth. ${ }^{14}$ In 1462-1465, he studied at the University of Freiburg. He was apprenticed to the new art with the printer Heinrich Eggestein in not very distant Strasbourg probably already during his studies, and he became a cleric (he was an illegitimate son of a priest). After his graduation, Riessinger left for Rome. From around 1467 , he ran a printing shop there, and he published at least ten titles after the spring of $1470 .{ }^{15}$ In 1467 , the other Italian prototypographers Sweynheym and Pannartz relocated to the papal city from nearby Subiaco. Shortly before them, the German Ulrich Han had established the very first printing shop in Rome. Probably after mid-1470, Riessinger moved to Naples, which had not had any printing shops, and founded the very first one to the south of Rome. Under Ferdinand I (1458-1494), Naples flourished both economically and culturally. The Aragonese Library in Castel Nuovo was one of the most acclaimed book collections of Italian rulers. ${ }^{16}$ Riessinger's printing shop also published official titles for the royal court, which hired other Humanists and could have commissioned him as a printer. Riessinger printed more than 50 titles in Naples. He primarily focused on juristic works, which constituted the most significant part of his production and were mainly sold to the local university. ${ }^{17}$ Most likely in 1473, he began to collaborate with the jurist of Naples Francesco Del Tuppo, who later often appeared as the publisher of his prints. Riessinger also printed significant Italian works (Dante Alighieri, La Commedia; Giovanni Boccaccio, Il Filocolo; Angelo Caracciolo, Dialogo di Polimaco e di Pilarcho). ${ }^{18}$ After Riessinger's return to Rome in 1478, Francesco Del Tuppo took over his workshop in Naples (including its German staff). Until early 1485, Sixtus ran his other printing shop in Rome before he terminated his typographical career and began pursuing the vocation of a priest in Strasbourg, like initially after his studies. ${ }^{19}$

The quarto-format print is set in Riessinger's large Roman type, slightly irregular and struggling (20 lines are $97 \mathrm{~mm}$ high). The type area is $133 \mathrm{~mm}$ high and $69 \mathrm{~mm}$ wide. The print has no title. It begins directly with the incipit, whose first line is set in the large Rotunda type for titles. The space for the initial at the beginning has been left

\footnotetext{
${ }^{14}$ FAVA - BRESCIANO 1911-1913, Vol. 1, pp. 10-27; GELDNER 1970, pp. 35-37; 126-129; SANTORO 1984, pp. 38-40; AMELUNG 2003; SCAPECCHI 2016.

${ }^{15}$ He published two bulls of Paul II there on 19 April 1470. Cf. GW M29908, M29910; ISTC ip00156900, ip00156800. Since none of his Roman prints have dates, there is no general agreement on the exact time of the beginning of his printing activity in Rome. See SCAPECCHI 1997 or NEEDHAM 2014, incl. abundant earlier bibliography on the beginnings of book printing in Rome.

${ }^{16}$ PONTIERI 1969, esp. pp. 123-139; HOLLINGSWORTH 2021, pp. 142-143.

${ }^{17}$ On juristic titles, see PANZANELLI FRATONI 2020, pp. 111-112.

${ }^{18}$ From about three hundred Naples incunabula, approximately 22 per cent are Italian, which exceeded the proportion of vernacular production in 15 th-century Italian letterpress printing. Hebrew printing took a great share ( 8 per cent) because of three Jewish printing shops. Until 1500 , there were about thirty typographers in Naples, but some had only marginal influence. The most productive of them was Johannes Moravus (57), active in Naples from 1475 until his death in 1492. Sixtus Riessinger (54) ranked right after him. Interestingly, the number of titles printed in Naples during the 1470 s was higher than over the next two decades. For more, cf. SANTORO 1984, esp. pp. 13-23; SANTORO 2003, pp. 48-50.

${ }^{19} \mathrm{ESCH} 1993$, p. 50.
} 


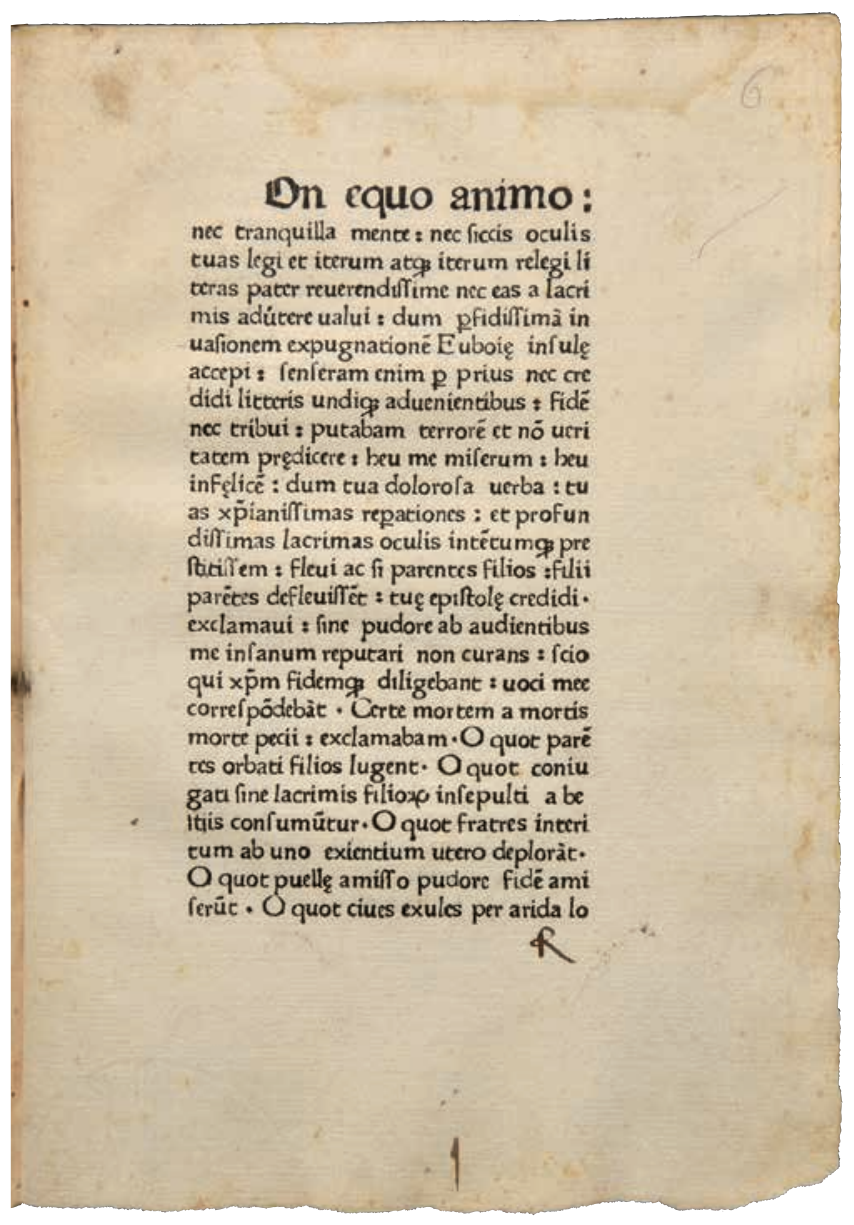

Fig. 1. The first page of the Lamentatio Nigropontis. National Library of the Czech Republic, shelf mark 44.G.75, fol. [a1r].

blank in the Prague print (Fig. 1). Riessinger used the two types during his initial stage in Naples until $1475 .{ }^{20}$ Only the colophon at the end is set in the majuscule for accentuation. It only states the place and year of publication without the printer's name: in Naples in 1470 (Fig. 2). As noted by Pietro Scapecchi in his short comment on the unique Prague copy, it remains uncertain whether the year refers to the date of printing. The colophon may refer to the time and place of origin of the Lamentatio Nigropontis. Scapecchi is inclined to think that it was in 1471 or at the end of $1470 .{ }^{21}$ It should be pointed out that Riessinger's first dated prints did not appear before 1471. Three voluminous juristic titles show only the year, not the day. ${ }^{22}$ The text of the Lamentatio was also spread as a manuscript. ${ }^{23}$ Regarding the manuscripts with which I am familiar, the date is listed in a contemporary

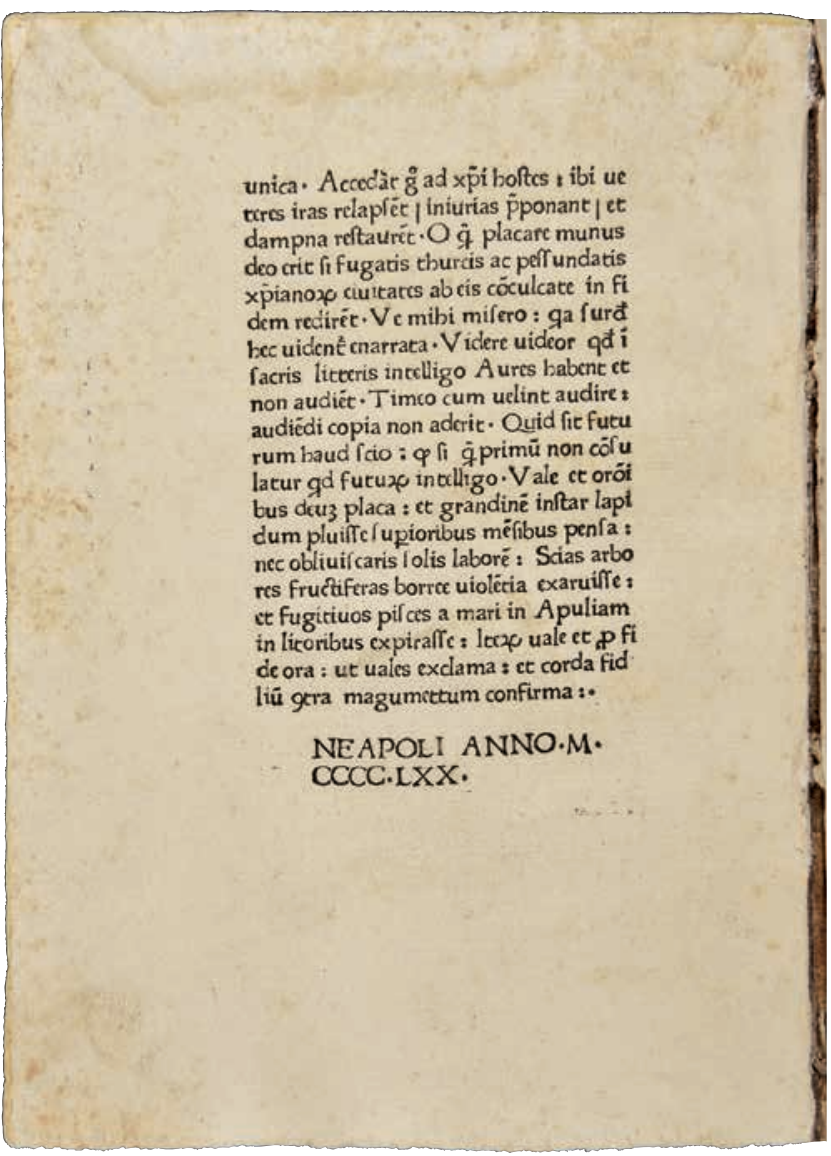

Fig. 2. The last page of the Lamentatio Nigropontis. National Library of the Czech Republic, shelf mark 44.G.75, fol. [a4v].

Central European copy in the Leipzig University Library. It is introduced by the title 'Epistola super devastatione civitatis que dicta est Negropont' and concluded with the date 'Neapoli anno MCCCCLXX Idus Novembris'. ${ }^{24}$ Therefore, the year 1470 appears to refer to the text, yet it may also have been the printing date. The terminus post quem for the print's origin is 13 November 1470 .

The print does not reveal any details about the Turkish attack and the fall of Negroponte. The unknown author chose the form of a consolation note addressed to Cardinal Bessarion, in which he responds to his information about the Turkish conquest of the island of Euboea. He laments over the lost lives: 'O quot parentes orbati filios lugent! O quot coniugati sine lacrimis filiorum insepulti a bestiis consumuntur! O quot fratres interitum ab uno exientium utero deplorant! O quot puellae amisso pudore fidem amiserunt! O quot cives exules per arida loca filios, coniunctos, sodales,

\footnotetext{
${ }^{20}$ FAVA - BRESCIANO 1911-1913, Atlante, tav. II, 2, 3; BMC, p. 854 (Types 98Ra, 180G, Plate 65); MAZAL 1984, p. 212; TW, Identifier: ma9187, ma09188. Permalink: http://tw.staatsbibliothek-berlin.de/ma09187. Incl. links to Riessinger's digitised prints set in these types.

${ }^{21}$ SCAPECCHI 2016

${ }^{22}$ GW 3488, 3506, 10078; ISTC ib00190400, ib00197800, if00225500; FAVA - BRESCIANO 1911-1913, Vol. 2, pp. 6-9, No. 11 (I, II), 14; SANTORO 1984, pp. 97, 148, Nos. 40-41, 261. Riessinger's activity in Naples at the end of 1470 cannot be ruled out but is not evidenced by any dated print. See SANTORO 1984, pp. 22-23, 39.

${ }^{23}$ Würzburg, Universitätsbibliothek, Inc.f.119, fols. 80r-81v; Wien, Österreichische Nationalbibliothek, cod. 3471, fols. 98v-100r; Firenze, Biblioteca Nazionale Centrale, cod. Magliabechiano, XXVII. 115, fols. 39r-42r.

${ }^{24}$ Leipzig, Universitätsbibliothek, cod. 1092 , fols. 364v-365v. See HELSSIG 1905, p. 233. Digitised version available at: https://digital.ub.unileipzig.de/object/viewid/0000029196. It will be useful to verify in future whether the Lamentatio Nigropontis originated in the circle of the aforementioned abbot of Naples Bessarion.
} 
concives magnis conatibus lacrimant suspirantque! ${ }^{25}$ and uses the emotional expression: 'Situs Calchidis et Euboie, quem nigrum vulgus appellat, cruore Christianorum rubicundus est factus. O quot capita et brachia insepulta iacent. $O$ quot membra fidelium a canibus sunt devorata' $\cdot{ }^{26} \mathrm{He}$ speaks about the wicked character of Mehmed, who covets control over Asia, Africa, and Europe, especially Rome. The terrifying tyrant, whose military power exceeds that of the most famous ancient commanders, expands everywhere. The Naples author remains anonymous, perhaps because of his criticism of the splendour-loving Pope Paul II. He sharply reproaches him for his little activity and his gathering of wealth, which should be used by the army instead: 'Tempus est enim, ut venalia ecclesie iocalia exponantur, aurum, argentum et que sacris inposita sunt, militibus distribuantur'. ${ }^{27}$ The author reminds the pope of the unfulfilled oath that he took during the conclave in August 1463 to continue the anti-Turkish crusade prepared by his predecessor Pius II. He appeals to him for remedy and calls for the conclusion of peace in Italy.

Up until now, the Lamentatio Nigropontis was known from a different edition, preserved in eight copies. It is a quarto-format print as well, but, unlike the Naples edition, it is introduced by the two-line title: 'Lamentatio Nigropontis ad Re[verendissimum] dominum dominum N. Cardinalem Nicenum'. After all, it remains unclear in the Naples edition whether the print was addressed to Bessarion, Cardinal of Nicaea, as there is no colophon. It appears to be later, and most bibliographies date it to 1472 or $1473 .{ }^{28}$ It comes from a Roman printing shop, in which another printer of German origin, Theobald Schenkbecher, published mostly thin prints around 1472-1475. ${ }^{29}$ Shortly before his death, the influential curial cleric and educated Spanish bishop Rodrigo Sánchez de Arévalo (Rodericus Zamorensis, † 4 October 1470) dedicated a consolation note to Bessarion. His Epistola de expugnatione insulae Euboiae dictae Nigropontis was issued approximately in $1470 / 1471$ by Ulrich Han, a printer in Rome, and Ulrich Zell, a Cologne printer. ${ }^{30}$

The unique Prague copy provides exciting information about Riessinger's early printing career in Naples. After the fall of Negroponte, the Kingdom of Naples and the Republic of Venice briefly became politically close. The inhabitants of the southernmost part of the Apennine Peninsula naturally felt the greatest risk of being attacked by an Ottoman fleet, and the ports of Naples and Sicily were on high alert. Riessinger offered them three thin titles on the history of
Negroponte. In addition to the Lamentatio, it was the versed composition Eubois, written by the Humanist Giorgio Fieschi (Georgius Fliscus), inspired by the first two books of Virgil's Aeneid and dedicated to Ferrante in the introductory poem. This twenty-folio print has been preserved in six copies, which are dated by incunabulists to $1471 .^{31}$ The third title was the Italian ballad Il pianto di Negroponte ('O tu dolce signor'), depicting the siege and plundering of the city as well as the courage of its defenders. Riessinger's edition on sixteen folios is now known from a unique copy deposited in the National Library in Naples. Similarly to the previous ones, this print has no colophon. Riessinger used the given type during 1471-1478, but this print was evidently produced during his initial stage in Naples, perhaps in 1471. ${ }^{32}$ Meserve believes, like in the case of the Latin titles about Negroponte, that the authors, Humanists (or editors) took the main initiative in their publication, dedicating them to prominent figures and seeking various benefits or career advancement: 'Indeed, these sonorous Latin editions [...] do look suspiciously like vanity publications, produced at the instigation, and possibly even the expense, of a class of aspiring civil servants and courtiers grasping for patronage and publicity'. ${ }^{33}$ The above-mentioned series of three of Riessinger's prints shows that she might have somewhat underestimated the commercial interest of typographers, often beginners, in similar, less financially demanding titles, in which readers probably showed interest when Italy was in danger.

During the Ottoman-Venetian War, La Serenissima also defended its domains on the eastern coast of the Adriatic Sea, but it lost most of them after the 1479 peace treaty. At the same time, the Ottoman army completed the subjugation of Albany. In 1480, ten years after the fall of Negroponte, the Ottoman fleet undertook two bold operations at the command of Mehmed II. On 23 May 1480, it disembarked on the island of Rhodes, which was held by the Knights Hospitaller. The Turks besieged the island's eponymous capital from the sea and from the mainland in an attempt to conquer it. On 27 July, they launched a frontal attack on the city's fortification. Spearheaded by the Grand Master, the defenders counterattacked. The Turks suffered severe losses, embarked on their ships and left during August. ${ }^{34}$ Nevertheless, the Turkish navy took a bolder action from the Alban port of Valona (today Vlorë). The Turkish fleet crossed the sea and about 18,000 Turks disembarked on the Salento Peninsula in the southeast of Italy on 28 July. Shortly afterwards, they

\footnotetext{
${ }^{25}$ Fols. [a1r-a1v].

${ }^{26}$ Fol. [a4r].

${ }^{27}$ Fol. [a3r].

${ }^{28}$ GW M27113; ISTC i100029040; CIH 2351; CIBN L-26; MESERVE 2006, p. 474 (No. 13). The digitised copy at the Bibliothèque nationale de France is available at: https://gallica.bnf.fr/ark:/12148/bpt6k58684fH.

${ }^{29}$ GELDNER 1970, p. 48.

${ }^{30}$ GW M38450, M38447; ISTC ir00212000, ir00213000; MESERVE 2006, p. 474 (Nos. 11-12).

${ }^{31}$ GW 9995; ISTC if00195000; BMC, p. 855; IGI 3977; CIE 2449; WALSH 3264; BSB-Ink F-134; FAVA - BRESCIANO 1911-1913, Vol. 2, pp. 32-33, No. 45; SANTORO 1984, p. 119, No. 135; MESERVE 2006, pp. 460-461, 474 (No. 8).

${ }^{32}$ GW M35254; ISTC i100029400; IGI 5642; SANTORO 1984, p. 126, No. 171; MESERVE 2006, pp. 455-456, 474 (No. 4). This composition was published in Florence and twice in Milan at that time: GW M35252; M35256; M3532020; ISTC il00029350; i100029450; il00029470; MESERVE 2006, pp. 454-458, 474 (Nos. 2, 3, 5).

${ }^{33}$ MESERVE 2006, p. 471.

${ }^{34}$ SETTON 1978, pp. 346-363; HOUSLEY 1992, pp. 111-112, 227-229; VATIN 2010.
} 
occupied the Otranto port and slaughtered the local inhabitants, including the clergy and its elderly archbishop. The disembarkation of the Turks in Apulia, which was part of the Kingdom of Naples, was another blow to the Christian world. The operation went smoothly in part because the Naples army was at war with Tuscany at that time; ${ }^{35}$ the Italians were worried that it was just a vanguard of the great Turkish invasion and campaign to Rome. The pope declared a new crusade and appealed to the Christian rulers to oust the Turks from Italian domains. Like in the case of the island of Rhodes, the finances were to be raised via plenary indulgences. The Franciscans and the Knights Hospitaller were put in charge of the indulgence campaign organisation. ${ }^{36}$ In the meantime, Mehmed II planned new disembarkation on the island of Rhodes; however, his death on 3 May 1481 and the subsequent internal political disputes over his successor temporarily mitigated the previous expansive military politics of the Ottoman Empire. Ferranate failed to obtain military support in feuding Italy for an extensive period of time. As many as 13 months later did the allied army, commanded by Ferrante's son Alfonso, finally succeed in the expulsion of the Turks from Otranto. Since the acute danger passed, the planned great anti-Turkish crusade was abandoned again.

The new Turkish offensive triggered a new media war, in which book printing played a substantial role. This time, the role of the printed media was significantly more intense than ten years earlier. The anti-Turkish press that was to stimulate the indulgence business swarmed Europe. Book printing was massively used to multiply papal indulgence bulls. Forms with personal data filled by hand served the individual indulgence recipients as a confirmation. The list of printed anti-Turkish titles from 1480-1482, including broadsides, consisted of 257 bibliography items. ${ }^{37}$ Especially the Knights Hospitaller were in the foreground and presented their victory over the Turks with skilful propaganda. They developed printed news about the course of the Turkish war that described the island of Rhodes as a solid outpost of Christianity and that received the favour of rulers and other financial aid for the order. Beginning in the autumn of 1480, reports mostly written by direct participants were published in the press. The most widespread among them was the Obsidionis Rhodiae urbis descriptio, in which Vice-Chancellor of the Knights Hospitaller Guillaume Caoursin vividly depicted the Turkish siege with all the drastic details; shortly afterwards, it was also issued in Italian, English, and German. ${ }^{38}$ The Kingdom of Naples took much less advantage of the me$\mathrm{dia},{ }^{39}$ and the Naples press contributed to it with only a single work. At the end of 1480 or in the first half of the following year, the Moravian native Johannes Moravus published the anti-Turkish composition Carmina contra Turcos there, in which the Augustinian monk Adam de Montaldo called for a crusade and the liberation of Otranto. ${ }^{40}$

Translated by Lucie Kasíková

\section{Bibliography:}

AMELUNG 2003: AMELUNG, Peter. Riessinger, Sixtus. In: Lexikon des gesamten Buchwesens. Band VI. Stuttgart: Hiersemann, 2003, pp. 312-313.

BABINGER 1978: BABINGER, Franz. Mehmed the Conqueror and His Time. Princeton: Princeton University Press, 1978.

BAK 2004: BAK, János $M$. Hungary and Crusading in the Fifteenth Century. In: HOUSLEY, Norman (ed.). Crusading in the Fifteenth Century. Basingstoke: Palgrave Macmillan, 2004, pp. 116-127.

BIANCHI 2016: BIANCHI, Vito. Otranto 1480: Il sultano, la strage, la conquista. Roma: Laterza, 2016.

BMC: Catalogue of Books Printed in the XVth Century Now in the British Museum. Part VI. Italy: Foligno, Ferrara, Florence, Milan, Bologna, Naples, Perugia and Treviso. London: Trustees of the British Museum, 1930.

BSB-Ink: Bayerische Staatsbibliothek. Inkunabelkatalog. Bd. 1-5. Redaktion Elmar Hertrich - Günter Mayer. Wiesbaden: Harrassowitz, 1988-2000.

CIBN: Bibliothèque Nationale. Catalogue des incunables. Tome 1-2. Paris: Bibliothèque Nationale de France, 1981-2006. CIH: Catalogus incunabulorum quae in bibliothecis publicis Hungariae asservantur. Vols. 1-2. Ediderunt Géza Sajó et Erzsébet Soltész. Budapestini: In aedibus Academiae Scientiarum Hungaricae, 1970.

DÖRING 2013: DÖRING, Karoline Dominika. Türkenkrieg und Medienwandel im 15. Jahrhundert. Mit einem Katalog der europäischen Türkendrucke bis 1500. Husum: Matthiesen, 2013.

EISERMANN 2011: EISERMANN, Falk. Der Ablass als Medienereignis. Kommunikationswandel durch Einblattdrucke im 15. Jahrhundert. In: HAMM, Berndt LEPPIN, Volker - SCHNEIDER-LUDORFF, Gury (edd.). Media Salutis. Gnaden- und Heilsmedien in der abendländischen Religiosität des Mittelalters und der Frühen Neuzeit. Tübingen: Mohr Siebeck, 2011, pp. 121-128.

ESCH 1993: ESCH, Arnold. Deutsche Frühdrucker in Rom in den Registern Papst Pauls II. Gutenberg Jahrbuch 1993, pp. 44-52.

\footnotetext{
${ }^{35}$ PONTIERI 1969, pp. 327-351; SETTON 1978, pp. 341-345; BABINGER 1978, pp. 389-396; THORAU 2006; HOUSLEY 2012, pp. 23, 94-96, 213; BIANCHI 2016.

${ }^{36}$ PAULUS 1923, pp. 205-209.

${ }^{37}$ DÖRING 2013, pp. 246-307.

${ }^{38}$ VAIVRE - VISSIERE 2014, pp. 299-488.

${ }^{39}$ DÖRING 2013, pp. 30, 93-136. Further cf. EISERMANN 2011, pp. 131-134; TAFIŁOWSKI 2012.

${ }^{40}$ GW M25291; ISTC im00817500; IGI 6702; SANTORO 1984, p. 132, No. 198; VOIT 2015, p. 114, No. A-003 (Fig. 1). Only five copies are known, one of which is in the library of the Premonstratensian Monastery at Strahov in Prague, shelf mark DM VI 14/6. It seems to have arrived in the Bohemian lands shortly after its publishing.
} 
FAVA - BRESCIANO 1911-1913: FAVA, Mariano BRESCIANO, Giovanni. La stampa a Napoli nel XV secolo. Vols. 1-2, Atlante. Leipzig: Rudolf Haupt 1911-1913.

GELDNER 1970: GELDNER, Ferdinand. Die deutschen Inkunabeldrucker. Ein Handbuch der deutschen Buchdrucker des XV. Jahrhunderts nach Druckorten. Bd. 2. Die fremden Sprachgebiete. Stuttgart: Hiersemann 1970.

GW: Gesamtkatalog der Wiegendrucke. Bd. I-VIII, Lfg. 1. Leipzig: Hiersemann, 1925-1940. Bd. VIII-XII, Lfg. 4. Stuttgart: Hiersemann, 1978-2020; Datenbank Gesamtkatalog der Wiegendrucke [online]. Staatsbibliothek zu Berlin [retrieved on 3 May 2021]. Accessible at: http:// www.gesamtkatalogderwiegendrucke.de/.

HELSSIG 1905: HELSSIG, Rudolf. Die lateinischen und deutschen Handschriften der Universitätsbibliothek Leipzig. Band 3. Die juristischen Handschriften. Leipzig: Harrassowitz, 1905.

HOLLINGSWORTH 2021: HOLLINGSWORTH, Mary. Princes of the Renaissance: The Hidden Powers Behind an Artistic Revolution. New York - London: Pegasus, 2021.

HOUSLEY 1992: HOUSLEY, Norman. The Later Crusades 1274-1580. From Lyons to Alcazar. Oxford: Oxford University Press, 1992.

HOUSLEY 2012: HOUSLEY, Norman. Crusading and the Ottoman Threat, 1453-1505. New York: Oxford University Press, 2012.

IBE: Biblioteca Nacional. Catálogo general de incunables en bibliotecas españolas. Tomo 1-2. Coordinado y dirigido por Francisco García Craviotto. Madrid: Ministerio de Cultura 1989-1990.

IGI: Indice generale degli incunaboli delle biblioteche d'Italia. Vols. 1-6. Roma: Libreria dello Stato, 1943-1981. ISTC: Incunabula Short Title Catalogue [online]. Consortium of European Research Libraries [retrieved on 3 May 2021]. Accessible at: https://data.cerl.org/istc

KALOUS 2017: KALOUS Antonín. Late Medieval Papal Legation. Between the Councils and the Reformation. Roma: Viella, 2017.

KODER 1973: KODER, Johannes. Negroponte. Untersuchungen zur Topographie und Siedlungsgeschichte der Insel Euboia während der Zeit der Venezianerherrschaft. Wien: Verlag der Österreichischen Akademie der Wissenschaften, 1973.

MAZAL 1984: MAZAL, Otto. Paläographie und Paläotypie. Zur Geschichte der Schrift im Zeitalter der Inkunabeln. Stuttgart: Hiersemann, 1984.

MERTENS 1991: MERTENS, Dieter. Europäischer Friede und Türkenkrieg im Spätmittelalter. In: DUCHHARDT, Heinz (ed.). Zwischenstaatliche Friedenswahrung in Mittelalter und Früher Neuzeit. Köln: Böhlau, 1991, pp. 45-90.

MESERVE 2006: MESERVE, Margaret. News from Negroponte: Politics, Popular Opinion, and Information Exchange in the First Decade of the Italian Press. Renaissance Quarterly, Vol. 52, 2006, pp. 440-480.

MOHLER 1923-1942: MOHLER, Ludwig. Kardinal Bessarion als Theologe, Humanist und Staatsmann. Bd. 1-3. Paderborn: Schöningh, 1923-1942.

MUREŞAN 2017: MUREŞAN, Dan. Bessarion's Orations against the Turks and Crusade Propaganda at the Große
Christentag of Regensburg (1471). In: HOUSLEY, Norman (ed.). Reconfiguring the Fifteenth-Century Crusade. London: Palgrave Macmillan, 2017, pp. 207-243.

NEEDHAM 2014: NEEDHAM, Paul. Sixtus Riessinger's Edition of Epistolae Hieronymi (GW 12420): circa (not after) 1470. La Bibliofilia, 116, 2014, pp. 17-43.

PANZANELLI FRATONI 2020: PANZANELLI FRATONI, Maria Alessandra. Printing the Law in the 15 th Century. With a Focus on Corpus iuris civilis and the Works of Bartolus de Saxoferrato. In: DONDI, Cristina (ed.). Printing R-Evolution and Society 1450-1500. Fifty Years that Changed Europe. Venezia: Edizioni Ca' Foscari, 2020, pp. 67-197.

PAPPAS 2014: PAPPAS, Vasileios. The First Political Printed Book in Europe: The Epistolae et Orationes Contra Turcos by Cardinal Bessarion. International Journal of Language and Literature. Vol. 2, No. 3, September 2014, pp. 37-55.

PASTOR 1904: PASTOR, Ludwig von. Geschichte der Päpste seit dem Ausgang des Mittelalters. Bd. II. Geschichte der Päpste im Zeitalter der Renaissance von der Thronbesteigung Pius'II. bis zum Tode Sixtus' IV. Freiburg im Breisgau: Herder, 1904.

PAULUS 1923: PAULUS, Nikolaus. Geschichte des Ablasses am Ausgang des Mittelalters (Geschichte des Ablasses im Mittelalter. Bd. 3). Paderborn: Schöningh, 1923. PETTEGREE 2014: PETTEGREE, Andrew. The Invention of News. How the World Came to Know about Itself. New Haven, CT: Yale University Press, 2014.

PG: MIGNE, Jacques-Paul (ed.). Patrologiae cursus completus. Series graeca. Vols. 1-161. Parisiis: Apud Garnier fratres, 1857-1866.

PONTIERI 1969: PONTIERI, Ernesto. Per la storia del regno di Ferrante I d'Aragona re di Napoli. Napoli: Edizioni scientifiche italiane, 1969.

SANTORO 1984: SANTORO, Marco. La stampa a Napoli nel Quattrocento. Napoli: L'Istituto Nazionale di Studi sul Rinascimento Meridionale 1984.

SANTORO 2003: SANTORO, Marco. Geschichte des Buchhandels in Italien. Wiesbaden: Harrassowitz, 2003.

SCAPECCHI 1997: SCAPECCHI, Pietro. Abbozzo per la redazione di una sequenza cronologica delle tipografie e delle edizioni romane degli Han e di Riessinger negli anni tra 1466 e 1470. RR. Roma nel Rinascimento, 1997, pp. 318-326.

SCAPECCHI 2016: SCAPECCHI, Pietro. REISSINGER, Sisto. In: Dizionario Biografico degli Italiani. Vol. 86 [online]. Istituto della Enciclopedia Italiana, 2016 [retrieved on 3 May 2021]. Accessible at: https://www.treccani.it/ enciclopedia/sisto-reissinger_(Dizionario-Biografico)/

SETTON 1978: SETTON, Kenneth M. The Papacy and the Levant (1204-1571). Vol. II. The Fifteenth Century. Philadelphia: The American Philosophical Society, 1978.

SCHMITT 2007: SCHMITT, Oliver Jens. Der ,tragische Untergang“ Negropontes im Spiegel italienischer Diplomatenberichte der Renaissance. In: BELKE, Klaus (ed.). Byzantina Mediterranea. Festschrift für Johannes Koder zum 65. Geburtstag. Wien - Köln - Weimar: Böhlau, 2007, pp. 569-580. 
SCHNEIDER 2000: SCHNEIDER, Cornelia. Mainzer Drucker - Drucken in Mainz I. In: Gutenberg. Aventur und Kunst. Vom Geheimunternehmen zur ersten Medienrevolution. Mainz: Stadt Mainz, 2000, pp. 190-211.

TAFILOWSKI 2012: TAFIŁOWSKI, Piotr. Turcica w Gesamtkatalog der Wiegendrucke. Kultura i Historia [online]. Instytut Kulturoznawstwa Uniwersytetu Marii CurieSkłodowskiej, Lublin 2012 [retrieved on 3 May 2021]. Accessible at: http://www.kulturaihistoria.umcs.lublin.pl/ archives 4296

THORAU 2006: THORAU, Peter. 'Turci ante portas'. Der osmanische Angriff auf Unteritalien 1480/81. In: PENTH, Sabine et al. (edd.). Europas Grenzen. St. Ingbert: Röhrig, 2006, pp. 93-118.

TW: Typenrepertorium der Wiegendrucke [online]. Staatsbibliothek zu Berlin [retrieved on 3 May 2021]. Accessible at: https://tw.staatsbibliothek-berlin.de/html/index.xql

VAIVRE - VISSIÈRE 2014: VAIVRE, Jean-Bernard de VISSIÈRE, Laurent. Tous les deables d'enfer. Relations du siège de Rhodes par les Ottomans en 1480. Genève: Droz, 2014.

VATIN 2010: VATIN, Nicolas. The Hospitallers at Rhodes and the Ottoman Turks, 1480-1522. In: HOUSLEY, Norman (ed.). Crusading in the Fifteenth Century. Basingstoke: Palgrave Macmillan, 2004, pp. 148-169.

VOIT 2015: VOIT, Petr. Katalog prvotiski Strahovské knihovny v Praze [A Catalogue of Incunabula of the Strahov Library in Prague]. Praha: Královská kanonie premonstrátů na Strahově, 2015.

WALSH 1991-1997: WALSH, James E. A Catalogue of the Fifteenth-Century Printed Books in the Harvard University Library. Vols. 1-5. Binghamton - Tempe: Harvard University Press, 1991-1997.

\author{
Kamil Boldan \\ National Library of the Czech Republic \\ Manuscripts and Early Printed Books Dpt. \\ Klementinum 190, 11001 Praha 1
}

